\title{
The place of animals in Kantian ethics
}

\section{Christine M. Korsgaard, Fellow creatures: our obligations to the other animals. Oxford University Press, Oxford, 2018, 252 pp, ISBN: 9780198753858}

\section{Jonathan Birch ${ }^{1}$ (D)}

Received: 12 September 2019 / Accepted: 3 October 2019 / Published online: 24 December 2019 (c) The Author(s) 2019

Kantian ethics has struggled terribly with the challenge of incorporating non-human animals as beings to which we can owe obligations. Christine Korsgaard's Fellow Creatures is a bold, substantial attempt to meet that challenge. It is a significant book. In this essay, I won't attempt a chapter-by-chapter summary. I will set the scene for the book's core argument (which comes rather late, in Chapter 8), offer a reconstruction of that argument, and reflect on its strengths and limitations. I'll also briefly compare the view at which Korsgaard arrives to that of Tom Regan in The Case for Animal Rights (1983).

\section{Kant's animal problem}

Kant's ethics, notoriously, assigns fundamental value to rational beings, where "rational" is understood in an unusually demanding sense. One might wonder whether even members of the species Homo sapiens possess the relevant kind of rationality, which, for Kant, seems to require an incompatibilist form of free will. Even if Homo sapiens qualifies, non-human animals seem clearly outside the scope of moral obligation. Fundamental worth, for Kant, goes with autonomy and moral agency. Non-human animals are not autonomous in the relevant sense, and they are not moral agents, so they have no fundamental worth. There is no room, within Kant's ethics, for a category of being to which we owe moral obligations even though it is not itself autonomous or bound by moral obligations.

Jonathan Birch

j.birch2@1se.ac.uk

http://personal.lse.ac.uk/birchj1

1 Department of Philosophy, Logic and Scientific Method, London School of Economics and Political Science, London, UK 
Suppose, for example, you torture a dog. You have not, in Kant's view, violated any obligations you owe to the dog. You have done the dog no wrong. A dog is not the sort of thing that can be wronged.

The problem here is not that the framework has yielded a one-off counterintuitive result. The problem is that, once you see that the framework (at least at first glance) regards animal suffering as morally irrelevant, the framework as a whole appears callous, inhumane, uninterested in the psychological side of suffering. It looks as though the theory doesn't care about suffering at all except in so far as it impairs the rational agency of the sufferer. It is, it seems, an ethical theory for the heartless. ${ }^{1}$

Kant himself grapples with this problem in the Metaphysics of Morals (Kant 1797/2017) although he does not, I think, appreciate its gravity. He offers a partial solution: we may not owe obligations to animals, but we can have obligations in regard to animals that we owe to ourselves. The idea is that, in torturing animals, killing them inhumanely, hunting them for sport or treating them without gratitude, one acts without due respect for one's own humanity. Why? Because mistreating animals dulls one's "shared feeling of their suffering and so weakens and gradually uproots a natural predisposition that is very serviceable to morality in one's relations with other human beings" (Kant 1797/2017, 6:433).

Kant's position is not simply that in mistreating animals I make myself more likely to wrong other people. It is rather that, in mistreating animals, I violate a duty I owe to myself by weakening my disposition for "shared feeling", or empathy. From the formula of humanity (discussed in more detail in the next section), I have a duty to cultivate morally good dispositions, and I violate this duty if I erode dispositions that are "serviceable to morality". This has come to be known as the "indirect duty" view.

Kant's view is not as ghastly as is sometimes claimed. Nozick (1974, p. 36), for example, suggested that the Kantian view would permit animal cruelty as long as the agent kept in mind a clear line between humans and animals, so that torturing animals did not in fact produce any "moral spillover" in the form of cruelty towards humans. Kant would reply that, even if no actual "spillover" occurs, the agent has violated a duty to himself by failing to cultivate a sense of empathy.

Even so, the view is still abominable. The deepest problem, as I see it, is that Kant's view makes our duties concerning animals dependent on contingent psychological facts about what does, or does not, erode our sense of empathy (a problem emphasized by Wood 1998). If Kant's psychological assumptions were shown to be incorrect for at least some humans, those humans would have no duties concerning animals. Consider, for example, people who are incapable of developing empathy, and therefore cannot erode that capacity by torturing an animal. It appears that, for Kant, they violate no duty by doing so.

Korsgaard is no fan of the "indirect duty" view. In Chapter 6, she notes some further problems, though they seem to me to be less serious. Kant, she suggests, takes

\footnotetext{
1 A line of criticism pressed by Broadie and Pybus (1974), Regan (1983) and Skidmore (2001). Regan's approach is nonetheless sometimes described as "broadly Kantian", and it bears some resemblance to Korsgaard's. I will revisit the comparison later.
} 
his position to imply that we should love the animals we own and express gratitude towards them, yet it is not clear that it is even possible to love sincerely, or to be grateful towards, a creature you regard as incapable of making any moral claim on you. Korsgaard's arguments here appear to rely on a partly cognitivist conception of love and gratitude, on which both constitutively involve judging the object to be valuable for its own sake. Kant could evade these complaints by appealing to a kind of quasilove or quasi-gratitude: simulacra with the affective components of love and gratitude in place, but with the cognitive components stripped away. He could say that we should quasi-love our animals, and be quasi-grateful for their service. But this only serves to underline the moral ugliness of the view, and its vulnerability to the deeper problem noted above.

\section{The formula of humanity}

Can a modern Kantian do better? In the Groundwork, Kant famously offers three "formulas" of the moral law (Kant 1785/2012). The second formula, the formula of humanity, commands us to "act that you use humanity, as much in your own person as in the person of every other, always at the same time as an end and never merely as a means" (4:429). The formula has a low-key role in the Groundwork, acting as a bridge between the formula of universal law ("act only according to that maxim through which you can at the same time will that it become a universal law", 4:421), which Kant introduces as the categorical imperative, and the idea of autonomy, which provides the metaphysical bedrock of Kant's ethics.

One might be forgiven for assuming Kant attaches relatively little importance to the second formula, which is given the apparently heuristic role of bringing the moral law "closer to intuition" (4:436). Yet, when Kant's thoughts turn to practical ethics in the Metaphysics of Morals, it's the second formula that seems to do most of the work. The formula of universal law turns out to be too abstract to yield useful moral guidance in the real world, so Kant repeatedly relies on the idea of humanity as an end-in-itself. Indeed, this is the formula that underlies the "indirect duty" view.

In earlier work, Korsgaard (1996a, b) recast the formula of humanity as the central principle in Kantian ethics, arguing that we could find in the Groundwork an argument for that principle that did not rely on prior endorsement of the formula of universal law. Here is Korsgaard's own summary of that argument, from a recent paper:

[B]ecause we are rational, we cannot decide to pursue an end unless we take it to be good. Most of our ends, however, are simply the objects of our inclinations, and the objects of our inclinations are not, just as such, intrinsically valuable. So we need some further story about why we take them to be good. That further story is that we attribute to ourselves the power to confer value on our ends by rationally choosing them. In so doing, we attribute a fundamental kind of value to ourselves. We attribute value to our own humanity, a property which Kant identifies with our capacity to determine our ends through rational choice. 
I summed this all up by saying that humanity is the unconditioned condition of all value, and as such, it must be valued. (Korsgaard forthcoming, pp. 1-2)

I find it helpful, for my own sake, to attempt to reconstruct arguments like this in a premise-conclusion format. So, here is my best attempt, with apologies to Korsgaard if it isn't quite right: ${ }^{2}$

\section{Argument for the formula of humanity:}

(Premise 1) We cannot rationally decide to pursue an end unless we take it to be good.

(Premise 2) We cannot take our ends to be good unless we take ourselves, qua rational agents, to be beings that confer value on ends by choosing them.

(Premise 3) A being that confers value on ends by choosing them is a being of fundamental value.

(Premise 4) We cannot take ourselves, qua rational agents, to be bearers of fundamental value unless we also take other rational agents to be bearers of fundamental value.

(Conclusion) We cannot rationally decide to pursue an end unless we take all rational beings to be bearers of fundamental value.

I leave out the word "humanity" because it is misleading. For Kant, "humanity" is a technical or quasi-technical term. As Korsgaard notes, it means what we would more naturally call "rational agency", the capacity to set our ends through rational choice. Note, then, that Kant is not "speciesist": he does not bake anthropocentrism into the core of his ethical framework. The framework is "logocentric" (rationality-centred) and its anthropocentrism is a contingent result of its logocentrism, on the assumption that Homo sapiens is the Earth's only rational species (Wood 1998; O’Neill 1998).

Much can be said and has been said about this argument (for a recent entry-point to the debate, see Bukoski 2018). I will have to limit myself to three brief notes. First, Premise 1 is not uncontroversial. It is a version of the idea that we act "under the guise of the good", and it expresses a demanding picture of what rational agency involves. I feel the pull of it, yet I also suspect that my obsession with acting "under the guise of the good" is more likely a contingent product of my enculturation than a deep truth about rational agency. If I eat a cake, I will agonise for a while about whether I can regard the eating of the cake as good-but I'd be no less rational, it seems to me, if I regarded eating the cake as bad and ate it anyway, deciding on this occasion to do something bad (Velleman 1992; Setiya 2007).

Second, the conclusion is tantalisingly conditional. It says that if we are to be capable of rational action in the sense required by Premise 1 (call it "big-R Rational action"), we must regard all rational beings as fundamentally valuable. Korsgaard wants us to use the conditional for a modus ponens, but we might also be tempted to use it in a modus tollens: "Sorry, I don't take all rational beings to be bearers of fundamental value — so I guess I'm just incapable of Rational action."

\footnotetext{
${ }^{2}$ Bukoski (2018, p. 200) offers a slightly different reconstruction.
} 
Third, I want to note the difficulty, at face value, of getting obligations towards non-rational animals out of this type of argument. The argument starts with a constraint that is allegedly built into the structure of rational agency: a "self-valuing" constraint. It then highlights the tension involved in taking oneself, qua rational agent, to be of fundamental value, while failing to see fundamental value in the rational agency of others. The way to resolve the tension is to take all rational agency, everywhere, to be of fundamental value. The only way to get a conclusion assigning value to non-rational animals from an argument with this general shape is to argue that rational agency builds in an even stronger self-valuing constraint than we initially supposed: to act rationally, we must value ourselves not just qua rational agents, but also qua animals.

This, it turns out, is exactly the move Korsgaard makes in Chapter 8 of Fellow Creatures.

\section{Extending the formula}

Here is how Korsgaard herself summarises her core argument towards the end of Chapter 8:

As rational beings, we need to justify our actions, to think there are reasons for them. That requires us to suppose that some ends are worth pursuing, are absolutely good. Without metaphysical insight into a realm of intrinsic values, all we have to go on is that some things are certainly good-for or bad-for us. That then is the starting point from which we build up our system of values-we take those things to be good or bad absolutely-and in doing that we are taking ourselves to be ends in ourselves. But we are not the only beings for whom things can be good or bad; the other animals are no different from us in that respect. So we are committed to regarding all animals as ends in themselves. (Korsgaard 2018, p. 145).

This is rather too brief to provide much insight into the structure of the argument. Indeed, it glosses over some of Korsgaard's subtlest moves. So, I will again take a stab at reconstructing the argument in a premise-conclusion form. My aim here is to highlight its structural similarities with the better-known argument in the previous section, while also bringing out the differences:

\section{The new argument: ${ }^{3}$}

(Premise $1^{*}$ ) We cannot rationally decide to pursue an end unless we take it to be good before deciding to pursue it.

(Premise 2*) We cannot take our ends to be good before deciding to pursue them unless we take ourselves, qua sentient beings, to be the sort of beings such that the satisfaction of our natural inclinations is good.

\footnotetext{
3 An early version of the argument appears in Korsgaard's (2004) Tanner Lectures, so it is not wholly "new", but in this book it receives its most detailed and careful presentation.
} 
(Premise $3 *$ ) A being such that the satisfaction of its natural inclinations is good is a being of fundamental value.

(Premise $4^{*}$ ) We cannot take ourselves, qua sentient beings, to be bearers of fundamental value unless we also take other sentient beings to be bearers of fundamental value.

(Conclusion*) We cannot decide to pursue an end unless we take all sentient beings to be bearers of fundamental value.

Note that, just as I omitted "humanity" from my reconstruction of the original argument, I omit "animal" from my reconstruction of the new argument. It too is misleading. For Korsgaard, "animal" is a quasi-technical term for any being that has subjective experiences with a valenced (positive or negative) character, such as experiences of pain, frustration, stress, anxiety, pleasure, joy and love. "Sentient being" is a better term for this. It leaves open the question of which animals in the biologist's sense are sentient beings. Some animals, such as jellyfish and sponges, may well be non-sentient. Others, such as arthropods, molluscs and fish, are sources of on-going debate (Birch 2017). Korsgaard doesn't need to take a stand on which animals are sentient and which are not, but it would be lamentable if animal ethics in general were to start using the term "animal" in a way that departs from its meaning in biology.

As I understand it, the logic of the new argument is the same as that of the old argument for the formula of humanity. The pivotal shifts are those from Premise 1 to Premise $1^{*}$ and from Premise 2 to Premise 2*. For Korsgaard, Kant's core mistake is this: Kant noticed our need to regard our ends as good once chosen, but he did not see that we also need to regard them as good in prospect, before we decide to pursue them. This led him to misjudge the nature of the presupposition that a rational being needs to make about its own value.

Kant thought that that, in order to act rationally, I must take myself qua rational decision-maker to be of fundamental value-so that, when I decide, my choices confer value on my ends. But this results in a picture on which my ends, viewed before I choose among them, are all on a par and equally worthless: whichever I select will thereby become good, but none is good in prospect. This, says Korsgaard, doesn't answer our need to regard our ends as good both before and after choosing to pursue them.

What Kant should have said, says Korsgaard, is that, in order to act rationally, I must take myself qua sentient being to be of fundamental value. As a sentient being, I experience natural inclinations (e.g. to eat when hungry, to sleep when tired) and these natural inclinations shape the range of options from which I can rationally choose. What I really need to presuppose, in order to act rationally, is that these options (when morally permissible) are good. That is, I need to presuppose that the satisfaction of my natural inclinations (when morally permissible) is good. It is good (and good absolutely_not just good for me) that I eat when hungry; it is good that I sleep when tired. So, I need to presuppose that the source of these inclinationssentience-is of fundamental value.

Now the rest of the old argument slots into place, with minor changes, around Premises $1^{*}$ and $2 *$. If I take myself qua sentient being to be of fundamental 
worth, then I must likewise take other sentient beings to be of fundamental worth. I can't rationally deny to other sentient beings the worth I take myself, qua sentient being, to have.

In short, and to oversimplify a little, Kant said "rational" when he should have said "sentient". His rationality-centred theory should have been sentience-centred, and it should be recast as such. Kantian ethics can be rehabilitated.

\section{The problem resurfaces?}

Or can it? Does the new argument work? It's not easy for me to project myself into the head of Korsgaard's orthodox Kantian opponent, but I can try. I'll assume this opponent grants Premise $1 *$ : they grant that, to act rationally, I must view my ends as good in prospect, not just as becoming good after they are rationally endorsed. I presume the orthodox Kantian would still want to resist Korsgaard's claim that we must substitute "sentient beings" for "rational beings" in Premise 2. I can see them arguing roughly as follows:

The old argument for the formula of humanity rests on considerations about what we must presuppose about our own value in order to act rationally at all. I grant that we can presuppose ourselves to be of fundamental value qua sentient beings, and not just qua rational beings. I even grant that we sometimes do presuppose this. But I doubt that we must presuppose this. For your argument to work, you have to show not just that we can and $d o$, but that we must. To do that, you'd have to find at least one clear example of an end that we must value even though it is not good for us qua rational beings, and I don't think you can do that.

Korsgaard considers a reply of this type in Section 8.5.4, and responds as follows:

[One might object] that I presuppose that what is good for autonomous rational beings, and only for autonomous rational beings, should be treated as good absolutely. But that conclusion is not driven by the argument .... And in fact it seems arbitrary, because of course we also value ourselves as animate beings. This becomes especially clear when we reflect on the fact that many of the things that we take to be good-for us are not good for us in our capacity as autonomous rational beings. Food, sex, comfort, freedom from pain and fear, are all things that are good for us insofar as we are animals. (Korsgaard 2018, p. 144)

This is a crucial passage, yet it does not, I think, deal with the objection. Korsgaard's list of activities that are "good for us insofar as we are animals" immediately suggests a divide-and-rule strategy for her orthodox Kantian opponent. Some of the activities in the list can be plausibly interpreted as activities that are also good for us qua rational beings, because they sustain the conditions 
in which our rationality can be exercised. Food, comfort, and freedom from pain and fear are in that category. These are not counterexamples to the claim that all I must presuppose, in order to act rationally, is that what is good for a rational being is good absolutely.

Sex is the odd one out in the list. If done solely in order to reproduce, perhaps it too (at a stretch) falls in the category of activities that are good for me qua rational being, because it helps perpetuate a community of rational beings. By contrast, if done for enjoyment, it is much less clear that there is any sense in which I must take it to be good absolutely. If I do so, this is just a contingent psychological fact about me. Many rational agents in human history, Kant himself among them, have seen no good in non-reproductive sex.

This raises the question of whether Korsgaard's list could be bolstered with better examples of activities that I must regard as good, even though they are not good for me qua rational being. I doubt it. I suspect the same divide-and-rule strategy can be extended across the board: the activities that I must regard as good are those that sustain my capacity for rational action, and activities that don't sustain my capacity for rational action need not be regarded by me as good, even if, as a matter of contingent fact about human psychology, some of these activities are extremely popular.

It's a familiar experience in philosophy that when you have grappled for a long time with a difficult problem and come up with a solution, the problem will resurface in a new guise, like a lump under the rug. This seems to be what is happening here. Our original problem was that, if you start with the Kantian idea that we must presuppose the fundamental value of our rational capacities in order to act rationally, it is possible to see how obligations towards other rational beings might follow (and Korsgaard has done more than anyone to show how they might follow), yet very hard to see how any obligations towards non-rational beings could follow.

Korsgaard now tells us that we can value ourselves qua sentient beings, and that many of us often do so, and that it is "arbitrary" to restrict our self-valuing to our rational nature alone. We might add: not just arbitrary, but also austere, monkish, self-denying, Vulcan-esque. But the charge of arbitrariness is not enough to turn a "can" into a "must", and nor are any of these other charges. Vulcans are still capable of rational action. The argument for the formula of humanity rests on premises about what we must presuppose in order to act rationally, and it is simply not true that we must presuppose the fundamental value of the non-rational parts of our nature in order to act rationally.

\section{The question of "abolitionism"}

Korsgaard's core argument is sure to generate substantial discussion. But I need to draw this essay to a close, and before I do that I should say something about the position at which Korsgaard ultimately arrives, and how it relates to more familiar "animal rights" positions. 
Korsgaard's view ends up surprisingly close to that of Regan (1983). Indeed, Regan is cited favourably several times. Korsgaard and Regan have reached similar end-points by very different routes. Regan felt the problem of animal cruelty mandated a rejection of Kant's rationality-centred ethics and its replacement by a new deontology based on the principle that all conscious "subjects of a life" have fundamental value. Korsgaard argues that Kant's own framework, when interpreted with care, already leads to the view that conscious subjects of a life have fundamental value, provided they have at least some valenced experiences (e.g. experiences of pain or pleasure). Strikingly, Korsgaard agrees with Regan that it is impermissible to kill animals for food or to use them for scientific purposes.

Yet Korsgaard parts ways with Regan in Chapter 12, where she argues against "abolitionism": the view that all human uses of animals should end. She declares a conflict of interest: the book is dedicated to her five cats. However, her core argument also gives her a reason to reject abolitionism. Korsgaard does not claim that all sentient beings are autonomous. The whole point is that we can argue that nonrational sentient beings have a form of fundamental value that does not require autonomy. This creates room for her to argue that it is autonomy, not sentience, that is morally incompatible with ownership.

For Korsgaard, "there is no reason to treat the other animals in a way that tries to mimic the particular kind of respect we owe to autonomous beings, because the other animals are not autonomous" (p. 219). What is morally required instead is that we treat the animal "in a way that is consistent with her good" (p. 226), where the animal's good consists in satisfying her natural inclinations for food, sex, comfort, freedom from pain and fear, and other things conducive to her survival and reproduction. Pet-keeping, Korsgaard argues, can be consistent with this requirement when done well (p. 235). The keeping of guide dogs, searchand-rescue dogs and police dogs is also permissible if the animal's good is respected (p. 226).

The abolitionist position at least has the virtue of clarity. The implications of Korsgaard's intermediate position are harder to tease out. Very many human uses of animals may be said, by their defenders, to be consistent with the animal's good. For Korsgaard, the spaying or neutering of pets is consistent with their good, even if they have a natural inclination to raise young, because we can provide our pets with "effective substitutes for the conditions and activities that are naturally good for them" (p. 233). The idea seems to be that we can satisfy our moral obligations by giving the animals in our care a good life, even if that life is circumscribed in important ways.

Given this qualification, it's no longer clear that Korsgaard's position implies the impermissibility of killing animals for food. In most societies around the world, the received wisdom is that farm animals raised for food can also be given good lives, even though their lives are circumscribed in important ways. Korsgaard faces the question: if curtailing an animal's reproductive capacity is consistent with its good, provided we treat it well in all other respects, why is curtailing the animal's lifespan by slaughter not also consistent with its good, provided we treat it well in all other respects? This tension is left unresolved. 


\section{Conclusion}

The arguments of this book are subtle, intricate and clever, and they deserve careful attention. The book is also unusually tasteful, from the lovely cover to the fine startof-chapter epigraphs from George Eliot, J.M. Coetzee, Darwin, Aristotle and others. Does it succeed in solving Kant's animal problem? I fear it does not. ${ }^{4}$

I expected to take issue with Korgaard's assumptions about biology, but this did not happen, the idiosyncratic usage of the word "animal" notwithstanding. Instead, it was the psychological assumptions that I found hard to digest. I am doubtful of the "guise of the good" assumption: the idea that we must take our ends to be good absolutely to act rationally. Accordingly, I can't buy the stronger assumption that we must take our ends to be good absolutely, even before we decide to pursue them, to act rationally. This stronger assumption is what the new argument needs. In short, even if Korsgaard could overcome the objection to Premise $2 *$ presented above, I would remain sceptical of Premise $1 *$.

The book falls within the long tradition of using strong assumptions about the nature of rational agency as a foundation for ambitious ethical theories. Kant showed us that, given some very strong assumptions, we must take rational agency to be of fundamental worth in order to act rationally. Korsgaard argues that, given an even stronger assumption of the same general type, we must take all sentient life to be of fundamental worth in order to act rationally. Those unmoved by arguments of this general shape will be unmoved by this one. Those with some prior sympathy for the Kantian approach may find themselves surprised by where the arguments lead.

Acknowledgements I thank Alex Voorhoeve and Angela Breitenbach for their comments and advice.

Open Access This article is distributed under the terms of the Creative Commons Attribution 4.0 International License (http://creativecommons.org/licenses/by/4.0/), which permits unrestricted use, distribution, and reproduction in any medium, provided you give appropriate credit to the original author(s) and the source, provide a link to the Creative Commons license, and indicate if changes were made.

\section{References}

Birch J (2017) Animal sentience and the precautionary principle. Anim Sentience 2(16). https://anima 1studiesrepository.org/animsent/vol2/iss16/1/. Accessed 24 June 2019

Breitenbach A (2009) Die analogie von vernunft und natur: eine umweltphilosophie nach Kant. De Gruyter, Berlin

Broadie A, Pybus EM (1974) Kant's treatment of animals. Philosophy 49:375-383

Bukoski M (2018) Korsgaard's arguments for the value of humanity. Philos Rev 127:197-224

Kant I (1785/2012) Groundwork of the metaphysics of morals, Gregor M (trans). Cambridge: Cambridge University Press

Kant I (1797/2017) The metaphysics of morals, Gregor M (trans). Cambridge University Press, Cambridge

Korsgaard CM (1996a) Creating the kingdom of ends. Cambridge University Press, Cambridge

Korsgaard CM (1996b) The sources of normativity. Cambridge University Press, Cambridge

\footnotetext{
4 Might there be other ways to find a place for animals in Kantian ethics? See Wood (1998), Timmermann (2005) and Breitenbach (2009) for other notable attempts.
} 
Korsgaard CM (2004) Fellow creatures: Kantian ethics and our duties to animals. In: Peterson GB (ed) The Tanner lectures on human values, volume 25-26. University of Utah Press, Salt Lake City. https ://tannerlectures.utah.edu/_documents/a-to-z/k/korsgaard_2005.pdf. Accessed 24 June 2019

Korsgaard CM (2018) Fellow creatures: our obligations to the other animals. Oxford University Press, Oxford

Korsgaard CM (forthcoming) Valuing our humanity. In: Sensen O, Dean R (eds) Respect for persons. http://www.people.fas.harvard.edu/ korsgaar/CMK.Valuing.Our.Humanity.pdf. Accessed 24 June 2019

Nozick R (1974) Anarchy, state, and utopia. Basic Books, New York

O’Neill O (1998) Kant on duties regarding nonrational nature II. Proc Aristot Soc 72:211-228

Regan T (1983) The case for animal rights. Routledge, London

Setiya K (2007) Reasons without rationalism. Princeton University Press, Princeton

Skidmore J (2001) Duties to animals: the failure of Kant's moral theory. J Value Inq 35(4):541-559

Timmermann J (2005) When the tail wags the dog: animal welfare and indirect duty in Kantian ethics. Kantian Rev 10:128-149

Velleman JD (1992) The guise of the good. Noûs 26:3-26

Wood AW (1998) Kant on duties regarding nonrational nature I. Proc Aristot Soc 72:189-210

Publisher's Note Springer Nature remains neutral with regard to jurisdictional claims in published maps and institutional affiliations. 